\title{
Correction to: Podophyllum derivatives containing fluorine atom in the 3-position of 2-aminopyridine improved the antitumor activity by inducing P53-dependent apoptosis
}

\section{Huai Wang ${ }^{1}$}

Published online: 28 November 2018

(c) Springer Science+Business Media, LLC, part of Springer Nature 2018

\section{Correction to: Medicinal Chemistry Research}

$$
\text { https://doi.org/10.1007/s00044-017-1841-x }
$$

The original version of this article unfortunately contained a mistake in Fig. 4. During the final submission of highresolution figures for this manuscript's publication, the images about P53 expression in Fig. 4 were inadvertently duplicated from the data of another synthesized compound in our lab.

The corrected version of the figure including P53 expression appears below. This correction does not change any conclusions of the paper.

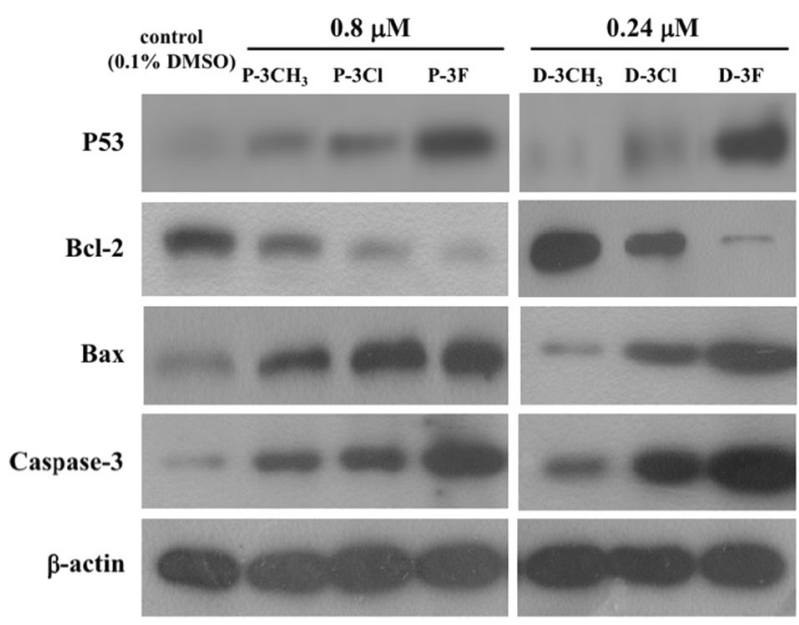

Fig. 4 Comparison to the effects of $\mathbf{P}-\mathbf{3 C H}_{3}, \mathbf{P}-\mathbf{3 C l}, \mathbf{P}-3 \mathbf{F}(0.8 \mu \mathrm{M})$ and D-3CH 3 , D-3Cl, D-3F $(0.24 \mu \mathrm{M})$ on expressions of apoptosisrelated proteins. HeLa cells were treated with different concentrations for $48 \mathrm{~h}$. Whole cell lysates were analyzed for expression levels of P53, Bcl-2, Bax, and caspase-3 by western blotting. Control represented the HeLa cells with $0.1 \%$ DMSO treatment. $\beta$-actin was used as a loading control
The original article can be found online at https://doi.org/10.1007/ s00044-017-1841-x.

Huai Wang

wonghuai@hotmail.com

1 School of Public Health, Nanchang University, 461 Ba Yi Avenue, 330006 Nanchang, Jiangxi, People's Republic of China 